\title{
Development of Papads: A Traditional Savoury With Purslane, Portulaca oleracea, Leaves
}

\author{
Ramachandran Renu, ${ }^{1, *}$ and Kavita Waghray ${ }^{1}$ \\ ${ }^{1}$ Department of Food Technology, University College of Technology, Osmania University, Hyderabad, Telangana State, India \\ *Corresponding author. Ramachandran Renu, Department of Food Technology, University College of Technology, Osmania University, Hyderabad, Telangana State, India. Tel: +91-4027098901, \\ Fax:+91-4027098472, E-mail: Renu.pillai96@gmail.com
}

Received 2015 February 5; Revised 2015 September 3; Accepted 2015 September 8.

\begin{abstract}
Background:Papads are cereal or legume based preserved products rich in proteins. Theyareconsumed after deep fat frying as a side dish in India. In the present work, the traditional savoury was chosen for value addition with green leafy vegetables i.e., purslane leaves. Legume based papads were prepared using black gram and purslane leaves with different amounts (10\%,15\%, 20\%, 25\%, and 30\%).

Objectives: The present study was conducted to develop value added traditional savoury with green leafy vegetables (purslane).

Materials and Methods: Physical and chemical analyses of the raw papads were carried out according to the Association of Analytical Communities (AOAC) methods. The fried papads were tested for oil uptake and also, subjected to sensory evaluation by semi-trained panelists.

Results: All the chemical constituents like moisture content, ash content, $\mathrm{pH}$, alkalinity, acid insoluble ash of all the different amounts were on par with the control, whereas ß-carotene content and crude fiber which were calculated theoretically increased as the percentage of incorporated green leafy vegetables increased. All the samples subjected for sensory evaluation were accepted equally by the panelists. Micronutrients, vitamins, and dietary fiber contents of green leafy vegetable papads increased remarkably.

Conclusions: This work gained satisfactory results in developing a nutritionally fortified and palatably accepted papads using purslane leaves.
\end{abstract}

Keywords: Papads Micronutrients, Dietary Fiber

\section{Background}

Papads are basically made from black gram, lentil, rice flour, potatoes, or sago with spices and condiments. The recipes and popularity of the snack differs depending upon the region of origin. Papads add taste to food, and have health benefits as its ingredients have multiple functions. Black gram is one of the most highly prized pulses of India. It is very nutritious and recommended for diabetics, as are other pulses (1). Like most other legumes, black gram is a good source of protein, minerals, and polysaturated fatty acids. It is deficient in methionine, but possesses lysine in excess. Therefore, blending it with rice and other foods has a complimentary effect and provides an increased level of sulfur-containing amino acids. Pepper is native to India and has been known to Indian cuisine since 2000 BC. Asafoetida works as a flavor enhancer. Papad Khar is an essential and vital ingredient in papads making and contributes to the organoleptic quality in terms of crispness and expansion of fried papads. A desirable crispy texture of papad can be made with a blend of rice flour (25\%), black gram (75\%), varying the moisture content of the dough (37.8\% - 41.5\%), and the thickness of papad sheet $(0.4-0.7 \mathrm{~mm})$ as well as flour with high water absorption values. Also the overall acceptability is moderately correlated to diametrical expansion and water absorption capacity (2). Papads are consumed after deep frying or roasting. Srinivasan et al. (3) developed minipapads (made of black gram) containing cheese powder ( $0 \%-50 \%)$ and found that they had a higher fat content on frying as compared to the control but with excellent organoleptically, making them a tasty and crunchy snack food.

The fat uptake for wheat-based papads incorporated with shepu (Peucedanum graveolens) and kilkeerae (Amaranthus tricolor) at different levels in fresh (15\% and $20 \%$ ) and dehydrated forms (5\% and $10 \%$ ) was similar to kilkeerae papads but shepu-incorporated papad showed slightly lower absorption compared to the plain papads. Minerals, vitamins, and fiber content of greens-incorporated papads increase remarkably (4). Sabharwal et al., (5) study was conducted on the effect of processing on field pea papads in terms of nutritional quality by analyzing proximate nutrients, total minerals, total sugars, antinutrients, in vitro protein, and in vitro starch digestibility using standard methods. Moisture content

Copyright ( 2015 , Health Promotion Research Center. This is an open-access article distributed under the terms of the Creative Commons Attribution-NonCommercial 4.0 International License (http://creativecommons.org/licenses/by-nc/4.0/) which permits copy and redistribute the material just in noncommercial usages, provided the original work is properly cited. 
Renu R et al.

of the field pea processed (by roasting) papad (8.10\%) was significantly lower than the unprocessed mixture (10.01\%). Results indicated that there were insignificant differences regarding crude protein, crude fat and total ash content of unprocessed mixture as well as processed field pea papad. Processing showed significant effect on iron content of the papad. The carbohydrate content of unprocessed and processed papad differed significantly. There was no significant difference in $\mathrm{Ca}$, and $\mathrm{Zn}$ content of unprocessed mixture. However, processed papad total soluble sugar of field pea papad (6.87\%) differed significantly from its unprocessed mixture (6.03\%). Pandey et al. (6) in their attempt to develop edible products from bamboo developed value added papads with bamboo shoots; they also conducted nutritional analysis, shelf life studies, and sensory evaluation for the same product and reported it as acceptable. Tarkergari et al. (7) examined 10 nutriDense products prepared using purslane (Portulaca oleracea) with respect to spinach incorporated dhal and vegetable mix (control). The nutrient content of the prepared recipes with reference to dietary fiber, protein, calcium, and iron were higher than the control.

Portulaca oleracea (common purslane, also known as verdolaga, pigweed, little hogweed or purslane) is an annual succulent in the family Portulacaceae, which can reach $40 \mathrm{~cm}$ in height. About 40 varieties of this family are currently cultivated (8). It is the earliest and nutritious vegetable used for human consumption, one of the richest green plant sources of omega-3 fatty acids and linolenic acid (9). It contains biologically active compounds such as free oxalic acids, alkaloids, flavonoids, and anthraquinone glycosides. Also, it is rich in vitamins such as vitamin A, C, B-complex, and micronutrients like iron, magnesium, calcium, potassium, and manganese. Purslane is used as a remedy for constipation and inflammation of the urinary system.

Though there is a high demand for papads, about $95 \%$ of the production of papad in the country is still at household level or in cottage scale (10). The demand for papad is uniformly and continuously increasing in all parts of the country because it is an inseparable part of Indian food. Moreover, there is a good chance of distribution of papad outside India.

\section{Objectives}

The present study aimed to develop papads enriched with purslane leaves.

\section{Materials and Methods}

\subsection{Papad Preparation}

All the ingredients were obtained from local market, cleaned, and weighed (Table 1). The ingredients were mixed with appropriate amount of water and made into a dough ball for control sample, also purslane leaves were added at different amounts (Table 2). After doughing, small round balls were rolled and pressed manually. Pressed round shaped papads were then sun dried.

\subsection{Physical Analysis of Papads}

The papads were prepared and their thicknesses were measured using screw gauge. From each level, 5 papads were analyzed and the average values was calculated. After drying, the diameter of papads was determined using ruler. Papads were fried in edible oil and the oil absorption was recorded with reference to weight difference before and after frying.

\subsection{Chemical Analysis of Papads}

Prepared papad samples were examined for proximate analysis and various chemical constituents, including moisture content, total ash, $\mathrm{pH}$ value, alkalinity, acid insoluble ash, according to the AOAC methods (11). Nutritive values of the developed products were computed using National Institute of Nutrition (NIN) food tables (12). Allmeasurements were done in triplicate and the results were expressed as the average value and tabulated.

\subsection{Sensory Evaluation of Papads}

The fried samples were subjected for sensory evaluation. A total of 30 semi-trained panelists judged the samples on a 9-point hedonic scale, where 9 denotes "dislike extremely" and 1 "like extremely" for attributes like color, appearance, texture, taste, flavor, after taste, and overall acceptability.

\section{Results}

The developed products have shown appreciable results. The diameters ranged between 9.5 and $11.0 \mathrm{~cm}$, which were on par with the Bureau of Indian Standards. Thickness ranged between 0.9 to $1.2 \mathrm{~mm}$ for control. Papads incorporated with $30 \%$ purslane leaves show the maximum thickness of $1.2 \mathrm{~mm}$ and papads incorporated with 20\% purslane leaves showing the least i.e., $0.9 \mathrm{~mm}$ (Table 3). All the chemical constituents like moisture content, ash content, $\mathrm{pH}$, alkalinity, acid insoluble ash of different samples were analyzed and found to be on par with the control. Moisture content in all the levels was found significantly different. Least moisture content recorded in control whereas the maximum moisture content was recorded in sample incorporated with $25 \%$ purslane leaves which was followed by samples with $10 \%, 20 \%$, $30 \%$, and $15 \%$ purslane leaves. Least ash content was found in papads incorporated with $10 \%$ purslane leaves and the maximum was recorded in papads incorporated with $30 \%$ purslane leaves. The results were according to the $\mathrm{Bu}-$ reau of Indian Standards. Results revealed that the maximum acid insoluble ash was in papads incorporated with $30 \%$ purslane leaves, whereas least was in papads incorporated with 10\% purslane leaves. Fat content as calculated 
Renu R et al.

theoretically was found to be between $1 \%$ and $2 \%$ (Figure 1). The present findings of $\mathrm{pH}$ and alkalinity value were according to the Bureau of Indian Standards (Table 4). Tarkergari et al. (7) carried out a study to explore the possibility of utilizing fresh and dehydrated purslane leaves and stalk in common dishes to increase the intake of greens as a source of micro and macro nutrients and concluded that dietary fiber, protein, calcium, and iron were higher than those in the control. Likewise in the present study, we observed that all samples were nutritionally good; calcium, iron, and carotene content remarkably increased (calculated theoretically) as the percentage of green leafy vegetables incorporated increased (Table 5).
The crude fiber content was also increased as the percentage of green leafy vegetables incorporated increased as shown in Figure 1. These findings are also in agreement with those reported by Kaveri et al. (4). Considering the data on oil absorption, no significant difference was observed among the levels compared to control. This result matches with the findings of Bhattacharya and Narasimha. (2), Kaveri et al. (4), and Sonawane et al. (13). All samples were equally accepted according to the scores given by the panelists (Table 6 ) for their color, texture, and appearance compared to control. But in terms of taste and flavor, papads with $15 \%$ of incorporated purslane leaves were preferred more over control.

Table 1. Recipe for Papad Preparation

\begin{tabular}{lc}
\hline Ingredient & Weight, g \\
\hline Black gram & 100 \\
Black pepper & 5 \\
Hing & 2 \\
Salt & 5 \\
Papad khar & 2.5 \\
\hline
\end{tabular}

Table 2. Levels of Green Leafy Vegetable Added

\begin{tabular}{lccc}
\hline Sample Number & Level & Black Gram, & \multicolumn{2}{c}{$\begin{array}{c}\text { Green Leafy Vegetable } \\
\text { Added, g }\end{array}$} \\
\hline- & Control & 100 & NA \\
\hline $\mathbf{1}$ & Control + Purslane & 100 & 10 \\
\hline $\mathbf{2}$ & Control + Purslane & 100 & 15 \\
\hline $\mathbf{3}$ & Control + Purslane & 100 & 20 \\
\hline $\mathbf{4}$ & Control + Purslane & 100 & 25 \\
\hline $\mathbf{5}$ & Control + Purslane & 100 & 30 \\
\hline
\end{tabular}

Abbreviation: NA, not available

Table 3. Evaluation of Physical Parameters of Papads

\begin{tabular}{lccc}
\hline Sample & Level & Thickness, $\mathbf{~ m m}$ & Diameter, cm \\
\hline- & Control & 1.2 & 9.6 \\
\hline $\mathbf{1}$ & Control + 10\% Purslane leaves & 1.1 & 11.0 \\
\hline $\mathbf{2}$ & Control + 15\% Purslane leaves & 0.9 & 9.5 \\
\hline $\mathbf{3}$ & Control + 20\% Purslane leaves & 1.0 & 10.5 \\
\hline $\mathbf{4}$ & Control + 25\% Purslane leaves & 1.1 & 10.0 \\
\hline $\mathbf{5}$ & Control + 30\% Purslane leaves & 1.2 & 10.8 \\
\hline
\end{tabular}


Renu R et al.

\begin{tabular}{lcccccc}
\hline \multicolumn{2}{l}{ Table 4. Chemical Analysis of Papads } & & & & \\
\hline Sample Number & Level & Moisture Content, \% & Ash content, \% & pH & Alkalinity & Acid Insoluble ash, \% \\
\hline Control & $\begin{array}{c}\text { Control } \\
\text { Control + 10\% } \\
\text { Purslane leaves }\end{array}$ & $12.9 \pm 0$ & $11.5 \pm 0$ & $7.8 \pm 0$ & $2.1 \pm 0$ & $0.23 \pm 0$ \\
$\mathbf{1}$ & $\begin{array}{c}\text { Control + 15\% } \\
\text { Purslane leaves }\end{array}$ & $13.8 \pm 0$ & $11.7 \pm 0.01$ & $7.01 \pm 0$ & $1.78 \pm 0.015$ & $0.195 \pm 0.015$ \\
$\mathbf{2}$ & $\begin{array}{c}\text { Control + 20\% } \\
\text { Purslane leaves }\end{array}$ & $14.0 \pm 0$ & $11.2 \pm 0$ & $6.97 \pm 0$ & $2.20 \pm 0.01$ & $0.3 \pm 0$ \\
$\mathbf{3}$ & $\begin{array}{c}\text { Control + 25\% } \\
\text { Purslane leaves } \\
\text { Control + 30\% }\end{array}$ & $14.4 \pm 0.01$ & $12.3 \pm 0.015$ & $7.04 \pm 0$ & $2.18 \pm 0$ & $0.37 \pm 0$ \\
$\mathbf{4}$ & Purslane leaves & $16.0 \pm 0.02$ & $13.1 \pm 0$ & $7.15 \pm 0$ & $2.4 \pm 0$ & $0.4 \pm 0.02$ \\
\hline
\end{tabular}

Table 5. Nutritive Analysis of Papads

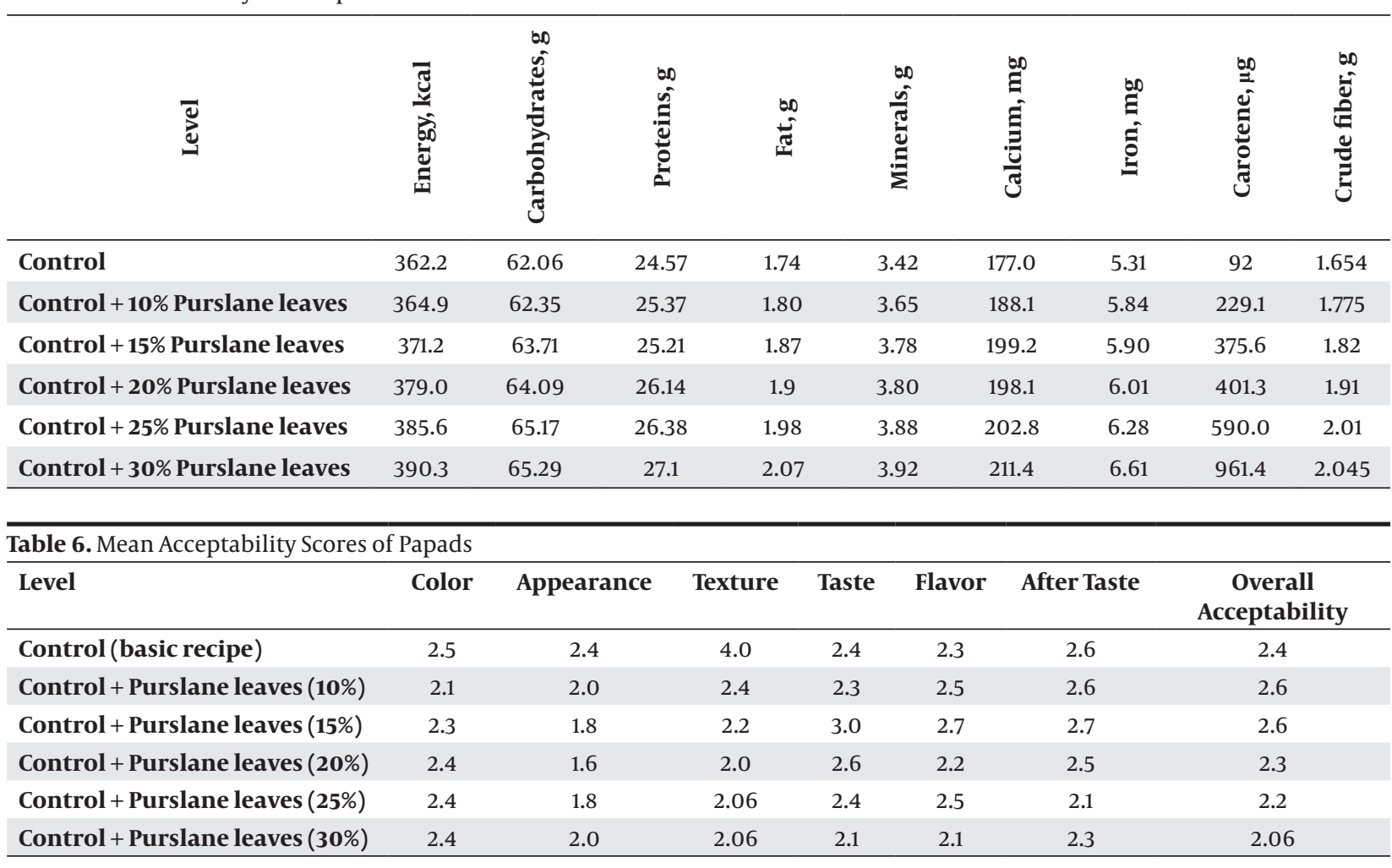

Figure 1. Variation in Fat and Crude Fiber

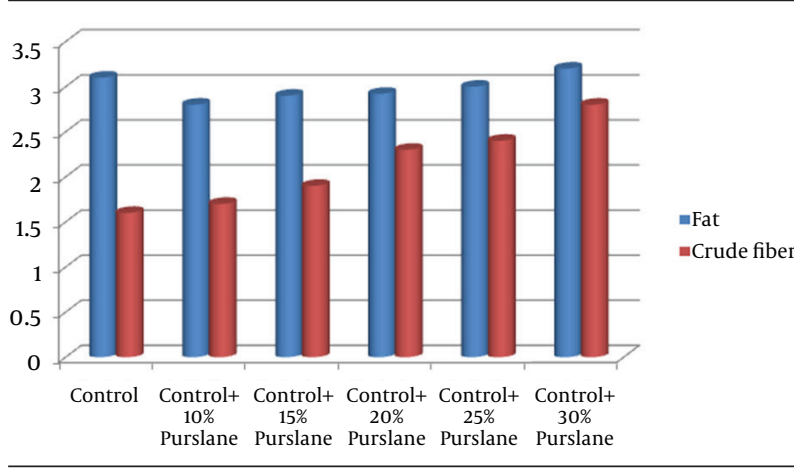

Based on Theoretically Calculated Nutrient Content (Table 5).

\section{Discussion}

This study gained satisfactory results in developing micronutrient enriched and palatably accepted papads using purslane leaves. Acceptability of papads in terms of physicochemical characteristics, sensory attributes, and nutritional quality suggests the suitability of papads with green leafy vegetables.

\section{Footnotes}

Authors' Contribution:Collection of raw material, product preparation and analysis, as well as data interpretation was carried out by Ramachandran Renu under the guidance of Kavita Waghray. Analysis and interpretation of data, drafting of the manuscript was done by Ramachan- 
Renu R et al.

dran Renu. Critical revision of the manuscript for important intellectual content was done by Kavita Waghray.

Financial Disclosure:Raw materials used for the study were purchased by the authors and the required chemicals and equipment were provided by the laboratories at Department of Food Technology, University College of Technology, Osmania University, Hyderabad, India.

Funding/Support:Study was supported and conducted by Department of Food Technology, University College of Technology, Osmania University, Hyderabad, India. There were no supportive funding agencies involved in the whole study. Product development, analysis and study were carried out at the department.

\section{References}

1. Azevedo L, Gomes JC, Stringheta PC, Gontijo AM, Padovani CR, Ribeiro LR, et al. Black bean (Phaseolus vulgaris L.) as a protective agent against DNA damage in mice. Food Chem Toxicol. 2003;41(12):1671-6. [PubMed: 14563392]

2. Bhattacharya S, Narasimha HV. Characterization Of Papad From Different Blends Of Cereals With Blackgram. J Food Qual. 2007;22(2):157-66.

3. Srinivasan P, Annapure US, Sahoo AK, Singhal RS, Kulkarni PR. Mini-papad containing cheese powder--a novelty snack food. Int J Food Sci Nutr. 2000;51(3):175-80. [PubMed:10945113]

4. Kaveri GV, Gupta S, Lakshmia J, Prakash J. Physicochemical characteristics and sensory attributes of wheat-based " papads" incorporated with green leafy vegetables. J Food Qual. 2004;27(6):459-70. doi:10.1111/J.1745-4557.

5. Sabharwal PK, Meenakshi G, Saroj D. Nutritional quality of value added papad from amylase rich flour of fieldpea. J Food Process Technol. 2012;3(10):28. doi:10.4172/2157-7110.S1.002.

6. Pandey Ak, Vijayalakshmi O, Choubey SK. Development and Shelf-life Evaluation of Value Added Edible Products from Bamboo Shoots. Am J Food Technol. 2012;7:363-71. doi: 10.3923| ajft.2012.363.371.

7. Tarkergari S, Waghray K, Gulla S. Acceptability Studies of Value added Products with Purslane (Portulaca oleracea). Pakistan J Nutrition. 2013;12(1):93-6. doi: 10.3923/pjn.2013.93.96.

8. Haar Milton J, Steven AF. Evaluation of Integrated Practices for Common Purslane (Portulaca oleracea) Management in Lettuce. Weed Technol. 2003;17(2):229-33. doi:10.1614/0890-037X.

9. Youssef KM, Mokhtar SM. Effect of Drying Methods on the Antioxidant Capacity, Color and Phytochemicals of Portulaca oleracea L. Leaves. J Nutrition Food Sci. 2014;4(6):1-6. doi: 10.4172/21559600.1000322

10. Annapure US, Michael M, Singhal RS, Kulkarni PR. Low-fat papadams from black gram-tapioca blends. Int J Food Sci Nutr. 1997;48(4):261-3. [PubMed: 9349443]

11. AOAC. Official methods of analysis. 13th ed. Washington D.C.: Association of official agricultural chemists; 2004

12. Gopalan C, Ramasastri BV, Balasubramanian SC. Nutritive value of Indian foods. Natl Institute Nutr, Indian council med res. 1999::60-2.

13. Sonawane SK, Vishwasrao CR, Arya SS. Effect of Incorporation of Green Leafy Vegetables on Bioactive Componenets of Papad- an Indian Snack Food. Indian J Nutr Diet. 2015;52(3):266-76. 